\title{
Anonimitas dan Deindividuasi pada Remaja Pengguna Sosial Media
}

\section{Tatik Mukhoyyaroh}

Fakultas Psikologi dan Kesehatan, UIN Sunan Ampel Surabaya

DOI: http://doi.org/10.29080/jpp.v11i1.354

\begin{abstract}
Deindividuation reduces individual self-awareness since they are more aware of themselves as group members and more responsive to the situation in group both negative (aggressive) and positive (prosocial). This study aimed to determine the correlation between anonymity and deindividuation among social media users. Having a quantitative research deign wth proportional stratified random sampling, the sample used was 100 teenagers from high school, vocational school, and Reigious High School. The instruments used were anonymity scale and deindividuation scale. Data were analyzed using product moment correlation. The results showed that there was a significant positive relationship between the anonymity variable and the deindividuation of adolescent social media users.
\end{abstract}

Keywords : Anonymity, Deindividuation, Social media

\begin{abstract}
Abstrak : Deindividuasi membuat self-awareness individu berkurang karena mereka lebih menyadari dirinya sebagai anggota kelompok dan lebih responsif terhadap situasi dalam kelompoknya baik negatif (agresifitas) maupun positif (prososial). Tujuan dari penelitian ini adalah untuk mengetahui hubungan anonimitas dengan deindividuasi pada remaja pengguna sosial media. Menggunakan design penelitian kuantitatif dengan proportional stratified random sampling, sampel yang digunakan berjumlah 100 remaja SMA, SMK, dan MA. Instrumen yang digunakan adalah skala anonimitas dan skala deindividuasi. Data dianalisis menggunakan korelasi product moment. Hasil penelitian menunjukkan terdapat hubungan positif yang signifikan variabel anonimitas dengan deindividuasi pada remaja pengguna sosial media.
\end{abstract}

Kata kunci : Anonimitas, Deindividuasi, Sosial media

\section{Pendahuluan}

Deindividuasi adalah bentuk perilaku (anti-sosial atau pro-sosial) dimana identitas, tanggung jawab, dan perilaku individu secara umum terendam ke dalam grup atau orang banyak (Madhavi \& Gebriel, 2017). Kendati fenomena deindividuasi lebih banyak dipengaruhi dari faktor eksternal, namun proses terjadinya fenomena 
deindividuasi dalam perilaku manusia tetap terjadi di dalam mindset individu. Hal itu dapat menyebabkan hilangnya batasan normal dalam berperilaku ketika berada dalam kerumunan sehingga dapat meningkatkan perilaku impulsif dan menyimpang (Aronson, dkk, 2013). Deindividuasi dapat menyebabkan hilangnya kewaspadaan diri dan ketidakmampuan mengevaluasi situasi ketika tidak dapat dikenali sehingga menyebabkan longgarnya norma-norma yang mempengaruhi perilaku individu (Myers, 2015). Reicher dan Posmest (1995), juga mengatakan hal yang sama bahwa kondisi deindividuasi membuat self awareness individu berkurang dan mereka lebih menyadari dirinya sebagai anggota kelompok sehingga lebih responsif terhadap situasi yang ada di dalam kelompoknya baik negatif (agresifitas) maupun positif (prososial).

Proses deindividuasi dalam diri seseorang dipengaruhi oleh beberapa faktor yang berasal dari kelompok itu sendiri seperti besar kecilnya suatu kelompok, anoninimitas, rasa saling memiliki antar individu dan euphoria yang timbul dari kelompok tersebut (Zimbardo, 2017). Wicaksono dan Irwansyah (2017) menggambarkan bahwa fenomena deindividuasi pada akun anonim banyak ditemukan pada sejumlah berita gosip di media sosial instagram. Menurut Reicher dan Posmest (1995) faktor penyebab deindividuasi adalah group immersion, anonimitas, dan hilangnya identitas. Group immersion adalah meleburnya individu di dalam kelompok sehingga individu tidak lagi melihat dirinya sebagai self-identity melainkan social identity. Anonimitas merupakan kondisi dimana identitas individu tidak dapat teridentifikasi. Hilangnya identitas (self-awareness dan self regulation) membuat individu kehilangan kesadaran diri dan kontrol diri menjadi salah satu faktor yang membuat seseorang mengalami deindividuasi.

Perkembangan arus informasi yang semakin pesat memunculkan teknologi baru seperti internet yang digunakan untuk berkirim pesan elektronik, mencari informasi, dan berkomunikasi dalam dengan media sosial (Setyani, 2013). Sebuah riset yang dipublikasikan oleh Crowdtap, Ipsos MediaCT, dan The Wall Street Journal pada tahun 2014 menunjukkan bahwa jumlah waktu yang dihabiskan untuk mengakses internet dan media sosial mencapai 6 jam 46 menit per hari (Nasrullah, dalam Mulawarman \& Nurfitri, 2017). Selanjutnya tahun 2018, perusahaan media asal Inggris bekerja sama dengan Hootsuite menemukan rata-rata warga Indonesia menghabiskan tiga jam 23 menit per hari untuk mengakses media sosial. Penelitian lain yang dilaporkan berjudul "Essential Insights Into Internet, Social Media, Mobile, and E-Commerce Use Around The World" menjelaskan dari total populasi Indonesia sebanyak 265,4 juta jiwa, pengguna aktif media sosialnya mencapai 130 juta dengan penetrasi 49\% (Pertiwi, 2018). Facebook merupakan media sosial dengan pengguna terbanyak di Indonesia mencapai 69 juta pada tahun 2014 sedangkan Twitter dengan 50 juta pengguna (Prihadi, 2015). Salah satu media sosial yang tergolong baru adalah Instagram dengan jumlah pengguna di seluruh dunia mencapai 300 juta (Khanza, 2014).

Hadirnya internet membuat banyak individu cenderung merasa lebih nyaman dan bebas untuk mengungkapkan diri dan informasi pribadi melalui interaksi online dibandingkan interaksi tatap muka (Joinson, 2001; Joinson \& Paine, 2006; Nguyen, Bin \& Campbell, 2012; Whitty \& Joinson, 2009; ). Namun dari sejumlah pengguna media sosial yang ada di seluruh dunia, banyak ditemukan akun yang anonim. Aronson, Wilson, dan Akert (2007) menegaskan bahwa individu yang tidak memberikan identitas (anonim) lebih sering mengatakan sesuatu yang tak pernah mereka katakan sebelumnya pada saat identitas mereka diketahui.

Menurut Sitorus (2014) anonim dalam media sosial adalah pengguna media sosial yang sama sekali tidak mencantumkan identitas mengenai dirinya di laman media sosial. Kondisi anonim dalam kelompok menyebabkan hilangnya kesadaran anggota sebagai individu yang mengakibatkan terjadinya deindividuasi (Chang, 2008) Selanjutntnya Christopherson (2007) menambahkan bahwa anonimitas adalah ketidakmampuan orang 
lain untuk mengidentifikasi individu atau orang lain. Survei yang dilakukan oleh youth IGF (internet governence forum) mengenai global prespective on online anonymity yang melibatkan 1.300 remaja dari 68 negara menemukan 65\% dari responden telah melakukan komunikasi tanpa memberikan identitas apapun (anonim) secara online selama satu tahun terakhir. Para remaja tersebut memberikan sejumlah alasan Amengapa mereka menyembunyikan identitasnya dalam berkomunikasi. Ada empat alasan utama mengapa pengguna media sosial tidak mencantumkan identitas mereka menurut survei tersebut yaitu agar merasa lebih aman, untuk melindungi reputasi mereka, menyenangkan dan agar mereka terhindar dari masalah (Global Perspective, 2013).

Pedersen (1997) menambahkan tiga alasan lainnya mengapa individu melakukan anonimitas yaitu untuk recovery, catharsis, dan autonomy. Recovery atau pemulihan adalah pembaruan yang melibatkan perenungan aktif terhadap situasi yang dihadapi dan menghasilkan relaksasi. Adapun catharsis atau katarsis adalah ekspresi pikiran dan perasaan yang tak terhindarkan kepada orang lain. Terakhir adalah autonomy atau otonomi yang melibatkan melibatkan kesempatan untuk bereksperimen dengan perilaku baru tanpa takut konsekuensi sosial. Anonimitas sangat berperan penting dalam membuat orang menjadi lebih bebas ketika ia berinteraksi secara online (Waskul \& Douglas, 1997). Semakin tinggi derajat anonimitas yang dipunyai oleh orang tertentu dalam interaksi online, maka semakin bebas dan berani seseorang untuk mengungkapkan dirinya. Hasil penelitian Smith dkk (2007) juga menyatakan bahwa dalam kondisi anonim, individu lebih konsisten dalam berperilaku dan mengekspresikan diri.

Reicher dan Posmest (1995) menyatakan bahwa deindividuasi sangat dipengaruhi oleh anonimitas dan peleburan individu dalam group. Sementara Taylor dkk., (2009) menggambarkan deindividuasi sebagai kondisi ketika adanya anonimitas kelompok yang menyebabkan individu tidak melakukan kegiatan tertentu sendiri. Anonimitas dalam media online dapat menimbulkan disinhibition effect, yaitu menjadikan seseorang kehilangan kontrol dan cenderung lebih bebas dalam perilakunya di dunia online (Suler, 2004). Berdasarkan fenomena-fenomena dan berbagai penelitian terkait yang telah dipaparkan di atas, peneliti memandang penting untuk melakukan penelitian lebih dalam mengenai hubungan antara anonimitas dengan deindividuasi pada remaja pengguna sosial media.

\section{Metode Penelitian}

Penelitian ini adalah penelitian korelasi. 100 partisipan yang terlibat dalam penelitian ini terdiri dari pelajar SMA,MA dan SMK di Surabaya yang dipilih dengan teknik sampling proportional stratified random sampling. Instrumen yang digunakan dalam penellitian ini adalah skala anonimitas dan skala deindividuasi. Teknik analisis data yang digunakan adalah korelasi product moment.

\section{Hasil Penelitian}

Subjek dalam penelitian ini sebanyak 100 siswa yang terdiri dari 19 orang laki-laki dan 81 perempuan. Rentang usia subjek mulai dari remaja berusia 15 tahun sebanyak 6 orang, 16 tahun 20 orang, 17 tahun 55 orang dan 18 tahun berjumlah 19 orang. Domisili subjek tersebar dalam beberapa wilayah Surabaya yaitu Surabaya Barat 25 orang, Surabaya Timur 25, Surabaya Utara 25 orang dan Surabaya Selatan 25 orang. Sebaran siswa SMA sebanyak 51 orang, SMK 42 orang, dan MA 7 orang yang berada di kelas 10 sampai kelas 12. Informasi lain adalah pekerjaan orangtua yang terdiri dari PNS/TNI/Polri sebanyak 9 orang, karyawan swasta 49 orang, wiraswasta 37 orang, petani/pedagang 2 orang dan ada 3 orang tidak disebutkan pada pilihan. Jumlah waktu 
penggunaan media sosial pun beragam mulai dari 1-2 jam sebanyak 23 orang, 2-3 jam 17 orang, 3-4 jam 25 orang, 4-5 jam 8 orang, dan lebih dari 5 jam 27 orang. Adapun media sosial yang digunakan meliputi whatsap, facebook, line, dan isntagram.

Hasil product moment correlation diperoleh nilai Beta 0.432 dengan taraf signifikansi sebesar 0.000 . Nilai $\mathrm{p}<0.05$ berarti kedua variabel mempunyai hubungan positif yang sangat signifikan. Nilai positif pada Pearson Correlation $(\mathrm{r}=+1)$ menunjukkan bahwa pola hubungan tersebut tergolong hubungan positif (searah). Dengan kata lain jika anonimitas tinggi, maka deindividuasi juga tinggi dan sebaliknya, jika anonimitas rendah, maka deindividuasi juga rendah.

Tabel 1

Koefisien Regresi

\begin{tabular}{|c|c|c|c|c|c|c|}
\hline & & Unstandardize & Coefficients & $\begin{array}{c}\text { Standardized } \\
\text { Coefficients }\end{array}$ & & \\
\hline & & B & Std. Error & Beta & $\mathrm{t}$ & Sig. \\
\hline 1 & (Constant) & 42.406 & 5.180 & & 8.186 & .000 \\
\hline & Anonimitas & .599 & .126 & .432 & 4.744 & .000 \\
\hline
\end{tabular}

a. Dependent Variable: Deindividuasi

Koefisien determinasi ( $\mathrm{r}$ square) dapat dilihat pada tabel ringkasan model regresi. Hasilnya diperoleh sebesar 0.187 menunjukkan proporsi varian dari variabel deindividuasi dapat dijelaskan oleh variabel predictor (anonimitas), artinya terdapat kekuatan positif sebesar $18.7 \%$ dari variabel deindividuasi yang dapat diterangkan melalui variabel prediktor.

Tabel 2

Ringkasan Model Regresi

\begin{tabular}{ccccc}
\hline Model & R & R Square & $\begin{array}{c}\text { Adjusted R } \\
\text { Square }\end{array}$ & $\begin{array}{c}\text { Std. Error of the } \\
\text { Estimate }\end{array}$ \\
\hline 1 & $.432^{\mathrm{a}}$ & .187 & .178 & 4.94046 \\
\hline \multicolumn{4}{c}{ a. Predictors: (Constant), Anonimitas } \\
b. Dependent Variable: Deindividuasi
\end{tabular}

\section{Pembahasan}

Hasil penelitian menunjukkan bahwa terdapat hubungan positif yang signifikan antara anonimitas dengan deindividuasi. Ketika anonimitas tinggi maka deindividuasi juga akan tinggi demikian sebaliknya, jika anonimitas rendah maka deindividuasi juga rendah. Hal tersebut didukung oleh penelitian Wicaksono dan Irwansyah (2017), tentang fenomena deindividuasi akun anonim yang banyak terjadi di berita gosip di media sosial instagram. Menurut para pemilik akun pada berita gosip mereka merasa aman dengan status anonimitas yang pada akhirnya membuat mereka mengalami deinviduasi. Semakin anomin, semakin tidak diketahui identitas diri seseorang, maka semakin deindividuasi orang tersebut. Anonimitas di sini memang terkadang meningkatkan agresifitas dalam deindividuasi akan tetapi ada peran konteks sosial yang akan menimbulkan perilaku prososial dalam deindividuasi.

Data subjek penelitian ini menunjukkan bahwa remaja SMA, MA dan SMK memiliki tingkat anonimitas yang tinggi dan sekaligus memiliki tingkat deindividuasi yang tinggi pula. Mereka memilih untuk menggunakan anonimitas karena menganggap itu berdampak menguntungkan. Jika individu membantu orang lain yang mengalami kesulitan maka anonimitas dianggap menguntungkan karena mengungkapkan hal-hal yang bersifat 
personal dan emosional melalui interaksi online menjadi lebih mudah. Namun sebenarnya anonimitas juga dapat berdampak merusak ketika individu yang terperangkap dalam perilaku negatif seperti bullying, pornografis, ataupun kekerasan visual ataupun verbal. Hal itu ditegaskan oleh Taylor dkk., (2009) bahwa deindividuasi yang dialami adalah dampak dari anonimitas kelompok sehingga para anggota tidak akan melakukan hal negatif saat mereka sendiri. Perilaku menutupi identitasnya dengan sengaja menurut Pedersen (1997) karena tiga alasan yaitu recovery, catharsis, dan autonomy. Recovery atau pemulihan yang memiliki arti sebagai rasa pemulihan atau pembaruan yang melibatkan perenungan aktif terhadap situasi seseorang dan menghasilkan rasa perlindungan dan relaksasi; Catharsis atau katarsis adalah ekspresi pikiran dan perasaan yang tak terhindarkan kepada orang lain; Autonomy atau otonomi melibatkan kesempatan untuk bereksperimen dengan perilaku baru tanpa takut konsekuensi sosial.

Anonim di media sosial juga dilakukan oleh banyak remaja di Indonesia. Mereka sama sekali tidak mencantumkan identitas mengenai dirinya di laman media sosial (Sitorus, 2014). Ada empat alasan mengapa pengguna media sosial tidak mencantumkan identitas, yaitu merasa lebih aman, melindungi reputasi, menyenangkan dan menghindar dari masalah (Global Perspective, 2013). Hal tersebut didukung dengan hasil penelitian Smith, et.al (2007) yang menyatakan bahwa dalam kondisi anonim, individu lebih konsisten dalam berperilaku dan mengekspresikan diri. Tingginya anonimitas membuat individu lebih bebas berinteraksi secara online sehingga deindividuasi mereka pun tinggi. Semakin tinggi derajat anonimitas yang dipunyai oleh orang tertentu dalam interaksi online, maka semakin bebas dan berani seseorang untuk mengungkapkan dirinya. Suler (2004) mengatakan bahwa anonimitas dalam media online dapat menimbulkan disinhibition effect, yaitu menjadikan seseorang kehilangan kontrol dan cenderung lebih bebas dalam perilakunya di dunia online. Kebebasan dalam perilaku di media online ini dapat berdampak menguntungkan dan juga merusak.

Namun Myers (2014) mengatakan bahwa individu yang mengalami deindividuasi akan kehilangan kewaspadaan terhadap dirinya sehingga mereka lebih mendukung respons terhadap norma kelompok. Remaja yang mengalami deindividuasi dalam penelitian ini terlihat lebih memilih kelompoknya daripada identitas dirinya. Ketika ada stimulus yang menyerang kelompoknya maka para remaja itu memiliki respon membela kelompoknya. Apa yang mereka lakukan itu dilihat sebagai sikap kompak dan solidaritas namun secaar tidak disadari mereka lupa akan identitas dirinya. Postmes dan Spears (1995) juga mengatakan hal yang sama dimana dalam kondisi deindividuasi maka self awareness individu berkurang dan mereka lebih menyadari dirinya sebagai anggota kelompok, dan lebih responsif terhadap situasi yang ada di dalam kelompok baik negatif (agresifitas) maupun positif (prososial).

Reicher dan Posmest (1995) juga menyatakan bahwa deindividuasi sangat dipengaruhi oleh anonimitas dan peleburan individu dalam group. Tingginya anonimitas pada subjek remaja dalam penelitian ini juga membuat mereka lebih menunjukkan dirinya sebagai bagian dari sebuah komunitas atau kelompok. Apa yang mereka lontarkan baik itu opini maupun penilaian sudah didasarkan pada kepentingan dan kebaikan kelompoknya. Hal itu juga yang dikatakan oleh penelitian sebelumnya yaitu individu cenderung merasa lebih nyaman dan bebas untuk mengungkapkan diri dan informasi sebagai pribadi lain melalui interaksi online dengan anonim dibandingkan interaksi tatap muka (Joinson, 2001; Paine \& Joinson, 2007; Nguyen, Bin \& Campbell, 2012; Whitty \& Joinson, 2009; ). Para pengguna merasa lebih bebas untuk berkomunikasi dalam ruang online dikarenakan hakikat media online sendiri yang pada derajat tertentu mampu membebaskan orang dari identitasnya keseharian yang melekat dalam dunia tatap muka.

Penelitian ini juga menunjukkan bahwa anonimitas mempengaruhi deindividuasi pada remaja SMA, MA, dan SMK pengguna sosial media di Surabaya sebesar $18.7 \%$ 
Sedangkan sisanya, sebesar 81.3\% dipengaruhi oleh faktor lain diluar anonimitas. Dengan kata lain kontribusi anonimitas sangat kecil dalam terbentuknya deindivusasi. Hal itu juga yang dijealskan oleh Reicher dan Posmest (1995) bahwa ada sejumlah faktor yang dapat menyebabkan terjadinya deindividuasi yaitu group immersion, anonimitas, dan hilangnya kesadaran diri. Kondisi anonimitas adalah saat identitas pribadi individu tidak dapat teridentifikasi sehingga mereka lebih merasa sebagai bagian dari kelompok. Demikian pula dengan hilangnya self- awareness yang membuat mereka lebih sadar akan apa yang terjadi dalam kelompok yang pada akhirnya membuat individu mengalami deindividuasi. Hal itu juga terlihat pada penelitian Kugihara (2001) yang menunjukkan bahwa efek dari perilaku agresif dan ukuran kelompok dimana semakin besar ukuran sebuah kelompok, maka semakin besar pula tingkat anonimitas. Penelitian yang mendukung pendapat di atas salah satunya yang pernah dilakukan oleh Ully (2016) tentang hubungan deindividuasi dengan perilaku agresi pelaku cyberbullying remaja. Hasil yang didapat menunjukkan adanya hubungan positif yang significant antara deindividuasi dengan perilaku agresi.

\section{Simpulan}

Anonimitas memiliki hubungan yang positif dan signifikan dengan deindividuasi sehingga ketika anonimitas tinggi, maka deindividuasi juga tinggi. Sebaliknya, jika anonimitas rendah, maka deindividuasi rendah. Anonimitas mempengaruhi terbentuknya deindividuasi pada remaja yang itu terlihat dari pola penggunaan remaja dalam menggunaakn media sosial. Sikap anonimitas dapat menjadi cara bagi para remaja untuk berhati-hati dan lebih bijak dalam menggunakan sosial media. Data angka yang diperoleh dari angket tidak dapat menggali apa yang menjadi alasan khusus para remaja melakukan anonimitas. Selain itu jumlah populasi yang digunakan dalam penelitian ini juga belum dapat memberikan informasi yang luas pada remaja lainnya di daerah luar Surabaya. Kecilnya nilai kontribusi anonimitas tehadap terbentuknya deindividuasi juga memberikan peluang untuk mengaitkan dengan variabel yang lain.

\section{Daftar Pustaka}

Aronson, E., Wilson, T. D., \& Akert, R. M. (2007). Social Psychology Sixth Edition. New Jersey: Pearson Prentice Hall.

Chang, J. (2008). The Role Of Anonymity In Deindividuated Behavior: A Comparison of Deindividuation Theory And The Social Identity Model Of Deindividuation Effects (SIDE) . The Pulse, 2.

Christopherson, K.M. (2007). The Positive and Negative Implications of Anonymity in Internet Social Interactions: "On the Internet, Nobody Knows You're a Dog". Computers in Human Behavior (23), 3038-3056.

Global Prespective. (2013). Global Perspective on Online Anonymity. Global: Youth IGF project.

Joinson, A. (2001). Self-disclosure in computer-mediated communication: The role of self-awareness and visual anonymity. European journal of social psychology. Wiley Online Library. https://doi.org/10.1002/ejsp.36.

Khanza. (2014). Jumlah Pengguna Capai 300 Juta, Instagram Kalahkan Twitter Retrieved from www.indoberita.com/2014/12/7823/Jumlah-Pengguna-Capai-300-JutaInstagramKalahkan-Twitter/, diakses pada 3 September 2019.

Kugihara, N. (2001). Effects of Agressive Behaviour and Group Size on Collective Escape in an Emergency: A Test Between a Social Identity Model and Deindividuation Theory. British Journal of Social Psychology, 40, 575-598. 
Madhavi, K., \& Gebriel/Okbit, W. (2017). Review of Deindividuation (Loss of SelfAwareness and Self-Identity) and Its Effect. The International Journal of Indian Psychology, 4(4), 75-82.

Mulawarman., \& Nurfitri, A.D. (2017). Perilaku Pengguna Media Sosial beserta Implikasinya Ditinjau dari Perspektif Psikologi Sosial Terapan. Buletin Psikologi, 25, 36-44.

Myers, D.G. (2015). Exploring Social Psychology Seventh Edition. New York: Hope College. Pedersen. D.M. (1997). Psychological Functions of Privacy. Journal of Enviromental Psychology, 17, 147-156.

Nguyen, M., Bin, Yu., \& Campbell, A. ( 2012). Comparing Online and Offline Self-Disclosure: A Systematic Review. Cyberpsychology, Behavior, and Social Networking. Vol. 15, No. 2.

Paine, C \& Joinson, A. (2006). Development of measures of online privacy concern and protection for use on the Internet. Journal of the American Society for Information Science and Technology. Willey Online Library. https://doi.org/10.1002/asi.20459.

Pertiwi, W.K. (2018). Riset Ungkap Pola Pemakaian Medsos Orang Indonesia. Retrieved from https://tekno.kompas.com/read/2018/03/01/10340027/riset-ungkappola-pemakaian-medsos-orang-indonesia, diakes pada 3 September 2018.

Prihadi, S. (2015). Berapa Jumlah Pengguna Facebook dan Twitter di Indonesia? Retrieved from http://www.cnnindonesia.com/teknologi/2 0150327061134-18542245/berapajumlah-pengguna-facebook-dan-twitter-di-indonesia, diakses pada 3 September 2018.

Reicher, S, R., S., \& Postmes, T (1995). A Social Identity Model og Deindividuation Phenomena. European Review of Social Psychology 6 (1).

Setyani, N.I. (2013). Penggunaan Media Sosial Sebagai Sarana Komunikasi Bagi Komunitas (Studi Deskriptif Kualitatif Penggunaan Media Sosial Twitter, Facebook, dan Blog sebagai Sarana Komunikasi bagi Komunitas Akademi Berbagi Surakarta). Jurnal Komunikasi Universitas Sebelas Maret Surakarta.

Sitorus, U.W.A. (2014). Hubungan Antara Deindividuasi dan Perilaku Agresi Pelaku Cyberbullying pada Remaja Pengguna ASK.FM di DKI Jakarta. Binus University.

Smith, J.R., et.al. (2007). Social Identity and the Attitude-Behavior Relationship: Effects of Anonymity and Accountability. European Journal of Social Psychology, 37, 239-257.

Suler, J. (2004). The Online Disinhibition Effect. Cyber Psychology \& Behavior vol. 7 no. 2

Taylor, Shelley E., $\quad$ Peplau, Letitia Anne., Sears David O. (2009). Psikologi Sosial (Edisi kedua belas). Jakarta: Kencana Prenada Media Group

Ully, W. A (2016). Hubungan Deindividuasi dengan Perilaku Agresi Pelaku Cyberbulying Remaja Pengguna ask.fm di Jakarta. Skripsi. Bina Nusantara University.

Waskul, D \& Douglas, M. (1997). Cyberself: The Emergence of Self In Online Chat. The Information Society 13:375-397.

Wicaksono, A., \& Irwansyah. (2017). Fenomena Deindividuasi dalam Akun Anonim Berita Gosip Selebriti di Media Sosial Instagram. Profetik Jurnal Komunikasi, 10(2), 34-45.

Whitty, M. T., \& Joinson, A. N. (2009). Online deception, fraud, spam and cons. Truth, lies and trust on the internet, 55-72. 